УДК 633.12:631.524.5

(C) 2013

Тригуб О. В., кандидат сільськогосподарських наук

Устимівська дослідна станція рослинництва Інституту рослинництва ім. В. Я. Юр'єва УААН

Ляшенко В. В., кандидат сільськогосподарських наук

Полтавська державна аграрна академія

\title{
ВЗАСМОЗВ'ЯЗОК ЕЛЕМЕНТІВ АРХІТЕКТОНІКИ РОСЛИНИ З УРОЖАЙНИМИ ХАРАКТЕРИСТИКАМИ У СОРТОЗРАЗКІВ ГРЕЧКИ ЗВИЧАЙНОÏ (FAGOPYRUM ESCULENTUM MOENCH.)
}

\section{Рецензент - кандидат сільськогосподарських наук М. М. Маренич}

Наведено результати вивчення набору колекиійних зразків різного еколого-географічного походження протягом 2001-2010 років за урожайними характеристиками (продуктивністю, крупноплідністю, урожайністю суцвіть) і морфологічними показниками (гіллястістю, кількістю суцвіть та вететативних вузлів на рослині, відношенням довжини зони гілкування до зони плодоношення). Зважаючи на значну генетичну різноманітність досліджуваного матеріалу, проведений аналіз отриманих результатів дає можливість виділити матеріал для різних напрямів селекції, що включатиме в себе не лише матеріал, відмінний за однією ознакою, але й є носієм комплексу господарськи иінних характеристик.

Ключові слова: гречка, урожайність, продуктивність, кількість суивіть на рослині, маса 1000 зерен, гіллястість, відношення довжини зони гілкування до зони плодоутворення.

Постановка проблеми. Враховуючи значне народногосподарське значення гречки, як традиційної національної культури, іiї цінність як незамінного продукту харчування, одного 3 найбільших медоносів, важливої ланки сівозміни та джерела матеріалів для переробної промисловості, останнім часом виробництву гречаної продукції в нашій країні надається значна увага. Дефіцит такого продукту харчування як гречана крупа, невиправданий ріст цін на неї вимагають від товаровиробників різкого підвищення обсягів виробництва гречки, який можливий, передусім, не завдяки збільшенню площ, а шляхом збільшення урожайності посівів. Низька продуктивність гречаної рослини обумовлена іiі біолого-ботанічними характеристиками, що сформувалися в процесі еволюційного розвитку, в процесі просування гречки з ареалу іiі виникнення до сучасних регіонів вирощування.

Незважаючи на вагомий вплив селекції на сучасний стан гречки, невирішеними наразі залишаються питання стабілізації обсягів вироб- ництва, а також різке зниження урожайності в несприятливі за водно-температурним режимом роки. Особливо це проявилося в останні 2-3 роки, коли недовиробництво гречаної продукції було обумовлено не лише зменшенням посівних площ під гречкою, а й негативним впливом підвищених температур та відсутністю опадів у літні місяці в основних гречкосіючих районах нашої країни.

Аналіз основних досліджень і публікацій, у яких розпочато розв'язання даної проблеми. Нині ринок сортового матеріалу гречки повністю забезпечений матеріалом різних селекційних установ і років селекції. Сформовано значний продуктивний i адаптивний потенціал, але наявні характеристики сортового матеріалу не в повній мірі відповідають вимогам сьогодення. Не усунена схильність гречаної рослини реагувати на покращання умов вирощування надмірним ростом за рахунок генеративної сфери, не всім сортам властива дружність цвітіння й достигання. Вирішити питання збільшення продуктивних характеристик сортів гречки i, головне, стабілізації їх рівня, неможливо без застосування у селекційному процесі нового вихідного матеріалу, віддаленого за своїм еколого-географічним походженням, - носія нової генетичної інформації. Джерелом принципово нового вихідного матеріалу для селекції може слугувати Національна колекція гречки, що нараховує близько двох тисяч сортозразків із понад двадцяти країн світу.

Значна частина Національної колекції гречки знаходиться на Устимівській дослідній станції рослинництва Інституту рослинництва ім. В. Я. Юр'єва НААН України (Полтавська область). Для вивчення екологічно різноманітного колекційного матеріалу та оцінки його адаптивного потенціалу на дослідній станції протягом 20012010 років проводилася закладка контрольного розсадника, де оцінювалася мінливість урожай- 
них характеристик зразків, елементів архітектоніки рослин та їх взаємозв'язки в різних умовах середовища.

Для характеристики урожайних параметрів застосувалися характеристики маси зерна 3 одного метра квадратного та рослини, крупність зерна, кількість зерен на рослині та в суцвітті. Для опису архітектоніки вегетативної системи зразків застосовували показники кількості гілок різних порядків (першого, другого та ін.), кількості вузлів на стеблі, кількості суцвіть на рослині. За результатами аналізу розраховувалася метамерійна формула зразка (середня кількість гілок та вузлів): Стебло $+\Gamma 1+\Gamma 2+\ldots$ Гn, а також відношення зони гілкування до зони плодоношення.

Дослідженнями окремих вчених [14] встановлено, що в процесі просування гречки як культури із півдня на північ значно скоротився як період вегетативного розвитку (період від сходів до цвітіння), так і весь вегетаційний період (сходи - достигання). Це стало результатом накопичення у сортових популяцій більш ранньостиглих складових компонентів і кількісне домінування їх над більш пізньостиглими. Середня кількість вузлів у зоні гілкування скоротилася 3 5,5 (українські зразки) до 3,4 шт. (у зразків північно-західного регіону), а вегетативних вузлів на рослині в цілому (на стеблі й гілках першого порядку) з 17,5 до 8,6 штук.

Мета досліджень - вивчення Національної колекції гречки звичайної (Fagopyrum esculentum Moench.) за показниками продуктивності (маси зерна $3 \mathrm{~m}^{2}$ та однієї рослини, кількості зерен на рослині та ін.) і характеристиками морфологічної будови рослини; встановлення рівня взаємозв'язку між ними в контрастних умовах оточуючого середовища.

Відповідно до поставлених завдань проведено оцінку набору зразків колекції різного еколого-географічного походження та виявлення генотипів iз різноманітними характеристиками озерненості, гіллястості, кількості суцвіть на рослині та ін.

Матеріали та методи досліджень. Для більш повної характеристики колекційного матеріалу в дослідження зв'язку архітектоніки 3 урожайними показниками було включено матеріал із чотирьох еколого-географічних груп гречки (за О. С. Кротовим) [7] та зарубіжні сортозразки походженням із Франції, Австралії, Японії, Ефіопії, Грузіі, Литви та Кореї. На жаль, не було технічної можливості залучити до випробування оригінальний матеріал (тобто той, який би не проходив відновлення схожості в нашій зоні). Відібрані для дослідження сортозразки вирощували без ізоляції, за принципом повної рендомізації розміщення ділянок, із використанням районованого сорту Українка за стандарт. Застосовувалася загальноприйнята технологія вирощування при широкорядному посіві (міжряддя складали 45 см) і нормі висіву 1,2 млн насінин на га та площею ділянки $5,4 \mathrm{~m}^{2}$ за трикратної повторності.

Всі обліки та спостереження проводили на рослинах, відібраних у середині кожної ділянки перед збиранням (по 20 рослин кожного зразка). У ході вивчення було використано «Методичні вказівки по вивченню колекційних зразків кукурудзи, сорго і круп'яних культур (просо, гречка, рис)» [6] та «Аналіз структури рослин гречки» (Методичні рекомендації) [3]. Погодні умови в роки досліджень характеризувалися значним різноманіттям за рівнем тепла й кількістю опадів, що дало можливість оцінити колекційний матеріал за показником стабільності прояву ознак.

У цілому група вивчення складалася 3 32-х зразків (2001-2003 рр.), 50-и зразків (2004-2006 рр.), 61-го зразка (2007-2009 рр.) та повного набору колекції попередніх років вивчення (143 зразки) - в 2010 році.

У даній статті подано середні показники для кожної з характеристик по 20-и проаналізованих рослинах, а також наведено перерахунковий рівень урожайності, що включав дані із відібраних рослин та густоти стояння рослинного матеріалу на період збирання.

Результати досліджень. Роботами М. В. Фесенко, Л. К. Тараненко та інших авторів [10; 13] відзначається, що найбілыш обумовлюючими урожайність ознаками $є$ індивідуальна насіннєва продуктивність генотипів, виражена кількістю i масою зерен із рослини $(\mathrm{r}=0,55)$. Продуктивність рослини - це комплексна ознака, що є результатом взаємодії сукупності морфологічних ознак i властивостей, які визначають особливості росту й розвитку рослин. Значення кожної окремо взятої ознаки із загального комплексу - різне. Підсумовуючими ознаками всіх складових $\epsilon$ озерненість (кількість зерен) і вага зерна 3 рослини [13].

Аналіз показника «вага зерна 3 рослини» вказує не лише на значне різноманіття прояву його у різного за походженням колекційного матеріалу, але й виявляє значний вплив умов вирощування на рівень вираження. Інтервал між мінімальним і максимальним рівнями 
СІЛЬСЬКЕ ГОСПОДАРСТВО. РОСЛИННИЦТВО

Характеристика урожайних показників гречки звичайноӥ (Fagopyrum esculentum Moench.) різного еколого-географічного походження

\begin{tabular}{|c|c|c|c|c|c|c|c|c|c|}
\hline \multirow{3}{*}{$\begin{array}{c}\text { Назва еколого- } \\
\text { географічної } \\
\text { групи }\end{array}$} & \multirow{3}{*}{$\begin{array}{c}\text { Кількість } \\
\text { зразків, } \\
\text { шт. }\end{array}$} & \multicolumn{8}{|c|}{ Показники } \\
\hline & & \multicolumn{2}{|c|}{ урожайність, г/м² } & \multicolumn{2}{|c|}{$\begin{array}{c}\text { продуктивність } \\
\text { рослини, г }\end{array}$} & \multicolumn{2}{|c|}{$\begin{array}{c}\text { кількість зерен iз } \\
\text { рослини, шт. }\end{array}$} & \multicolumn{2}{|c|}{$\begin{array}{c}\text { маса } \\
1000 \text { зерен, г }\end{array}$} \\
\hline & & середнє & $\min -\max$ & середнє & $\min -\max$ & середнє & $\min -\max$ & середнє & min-max \\
\hline $\begin{array}{c}\text { Стандарт } \\
\text { (с. Українка) }\end{array}$ & & 284,5 & $126-416$ & 2,36 & $\begin{array}{l}1,11- \\
3,58\end{array}$ & 82,5 & $42-119$ & 28,6 & $\begin{array}{c}26,5- \\
30,2\end{array}$ \\
\hline $\begin{array}{c}\text { Середньостигла } \\
\text { південна }\end{array}$ & 74 & 218,8 & $\begin{array}{l}92,5- \\
519,0\end{array}$ & 1,86 & $\begin{array}{c}0,50- \\
4,56\end{array}$ & 76,6 & $36-126$ & 26,6 & $\begin{array}{l}22,0- \\
36,1\end{array}$ \\
\hline $\begin{array}{c}\text { Скоростигла } \\
\text { північна } \\
\end{array}$ & 24 & 209,1 & $\begin{array}{l}100,4- \\
377,0\end{array}$ & 1,74 & $\begin{array}{l}0,84- \\
3,50\end{array}$ & 69,1 & $35-101$ & 26,2 & $\begin{array}{l}22,0- \\
31,1\end{array}$ \\
\hline $\begin{array}{c}\text { Середньостигла } \\
\text { гірська }\end{array}$ & 16 & 182,3 & $\begin{array}{l}87,0- \\
262,1\end{array}$ & 1,55 & $\begin{array}{l}0,55- \\
2,51\end{array}$ & 58,6 & $31-96$ & 27,3 & $\begin{array}{l}22,0- \\
32,0\end{array}$ \\
\hline $\begin{array}{c}\text { Пізньостигла } \\
\text { приморська }\end{array}$ & 21 & 203,1 & $\begin{array}{r}78,3- \\
343,0 \\
\end{array}$ & 1,70 & $\begin{array}{c}0,63- \\
3,13\end{array}$ & 57,7 & $38-102$ & 26,1 & $\begin{array}{l}24,0- \\
28,8\end{array}$ \\
\hline $\begin{array}{c}\text { Зразки з далекого } \\
\text { зарубіжжя }\end{array}$ & 8 & 155,2 & $\begin{array}{l}69,5- \\
280,0\end{array}$ & 1,36 & $\begin{array}{l}0,58- \\
3,00\end{array}$ & 58,1 & $42-98$ & 26,7 & $\begin{array}{l}24,0- \\
30,6\end{array}$ \\
\hline $\begin{array}{c}\text { Середнє по групі } \\
\text { вивчення }\end{array}$ & & 209,3 & $\begin{array}{l}69,5- \\
519,0\end{array}$ & 1,16 & $\begin{array}{c}0,58- \\
4,56 \\
\end{array}$ & 68 & $16-207$ & 26,6 & $\begin{array}{c}22,0- \\
36,1\end{array}$ \\
\hline
\end{tabular}

продуктивності становить 3,98 г, за найменшої продуктивності 0,58, а найбільшої 4,56 г із рослини. Підтвердженням цього $є$ рівень варіювання ознаки, коефіцієнт варіації по групі вивчення становив $36,6 \%$, із розподілом по роках від 17,3 до $46,7 \%$. Найбільшою продуктивністю характеризуються зразки середньостиглої південної групи, дещо меншою - скоростиглої північної, що можна пояснити кращою пристосованістю цього матеріалу до місцевих умов вирощування, більшим проявом їх адаптивного потенціалу жаровитривалості та посухостійкості (табл. 1).

Аналогічне становище і 3 показником «кількість зерен на рослині». Аналіз результатів групи вивчення вказує на значну залежність цього показника як від походження матеріалу, так i від погодних умов. Коефіцієнт варіації становив $31,1 \%$ із коливаннями по роках від 12,4 до $38,9 \%$. Найменшу кількість зерен на рослині формували зразки середньостиглої гірської групи, а найбільшу - середньостиглої південної. Встановлено коливання цього показника від 16 до 207 штук на рослині. Розмах варіювання становив 191 зерно, за середнього показника 68 зерен (див. табл.).

У селекційній роботі на якість основними напрямами $\epsilon$ вихід крупи та ядриці, що обумовлюється показником «маса 1000 насінин» (крупності) та плівчастості зерна. Масовим добором за крупністю зерна був виведений сорт Богатирь. За П. А. Сіриком [9], багаторазовий добір за крупністю насіння підвищує урожайність зерна, а також відсоток крупних плодів в урожаї. Врожайність від такого добору збільшується на $8-11 \%$. Шляхом добору за крупністю i продуктивністю створений сорт гречки Шатилівська 5 [1], а Н. Н. Петеліною [8] із сортів Примор'я, Китаю та Японії, - сорти Краснострілецька, Майська, Троянда та ін.

Проведений аналіз маси 1000 зерен підтверджує дані багатьох дослідників про значну обумовленість величини цього показника генотипом. Коефіцієнт варіації у групі вивчення становив $10,3 \%$ і варіював у межах 7,6-15,3\%. Розмах варіювання ознаки знаходився в межах від 22,0 до 36,1 г, за середнього значення $-26,6$ г із варіаційним розмахом 14,1 г. Найбільш крупне зерно формувалося колекційним матеріалом із середньостиглої південної групи. Серед сортозразків інших груп також зустрічався матеріал, що мав крупне зерно, але часто крупність визначалася підвищеною крилатістю матеріалу з низьким виходом крупи (див. табл.).

Урожайність, як основна характеристика продуктивного потенціалу сорту, складається внаслідок впливу всіх факторів оточуючого середовища на рослинний організм у період росту й розвитку. Величина iї $\epsilon$ результатом компромісу між реалізацією генетичного потенціалу продуктивності та стійкістю до несприятливих факторів довкілля [5]. Найвищою урожайністю за період проведення досліджень характеризувалися зразки середньостиглої південної групи, чий потенціал урожайності 
реалізовувався у звичних для даного матеріалу умовах. Сортозразки контрастних екологогеографічних груп (пізньостиглої приморської та скоростиглої північної) мали підвищену реакцію на зміни умов середовища. В сприятливі за водно-температурним режимом роки приморські зразки показали себе пізньостиглим, із низькою дружністю достигання, високорослим матеріалом. Вони формували значну листостеблову масу та високу урожайність зерна. Зате в разі погіршення умов вирощування урожайність цих сортів була досить низькою, що й призвело до нижчого його рівня, ніж середній у загальної групи вивчення. Сортозразки ж скоростиглої північної групи особливо походженням із північних регіонів Російської Федерації мали меншу потенційну врожайність i, незважаючи на знижену реакцію на зміну погодних умов, не мали рівного зі стандартом рівня урожайності (див. табл.).

У результаті проведення досліджень встановлено існування значного різноманіття характеристик матеріалу в середині кожної сортової популяції. Отримано підтвердження висунутої М. М. Фесенко та I. А. Гуринович теорії про неоднорідність популяцій та обов'язкову наявність у них незначної кількості морфотипів, що займають крайні положення в популяціях за кількісними характеристиками вегетативної сфери (кількість гілок та вузлів). Ці особини відіграють страхову роль у популяції, забезпечуючи ій виживання у випадках різких змін середовища й $\epsilon$ адаптивним ядром популяції за таких змін. Ця особливість є видовою ознакою, а ii реалізація забезпечується за рахунок спеціальних генетичних механізмів, що блокують появу в нащадків рослин гомозигот зміни кількості вузлів і гілок навіть у разі використання інцухтування [16].

Встановлено, що найбільшою гіллястістю (кількістю гілок першого, другого та інших порядків) вирізнялися рослини пізньостиглої приморської групи та зразки походженням із Китаю. Ці рослини формували від 16-и до 28-и гілок на одній рослині й на зміну величини цього показника не проявляли значного впливу погодні умови років вирощування. Найменш гіллястими виявився матеріал із скоростиглої північної групи (3-12). Проте серед цієї групи виявлено розподіл величини показника залежно від регіону походження. Найменшу кількість гілок формували рослини із більш північних районів (Московська, Архангельська та ін.). Цей же матеріал виявився більш скоростиглим i низькорослим. Значно більшою кількістю гілок характеризувалися сортозразки із цієї ж групи, але походженням із Республіки Білорусь. У цілому можна зробити висновок про значну неоднорідність матеріалу кожної 3 екологогеографічних груп за цим показником.

Іншою, не менш важливою характеристикою архітектоніки зразка, $\epsilon$ кількість суцвіть на рослині. Окремими дослідниками, які працювали 3 гречкою, висунуто теорію залежності продуктивності рослин гречки від характеристики суцвіть гречаної рослини (їх кількості, розподілу на рослині та ін.). Так, Л. Тараненко та А. Бобер [11] у селекційній роботі застосовували показник продуктивності суцвіття (співвідношення маси зерна до кількості суцвіть на рослині), а О. Горіна [4] запропонувала показник фертильності елементарних суцвіть (співвідношення кількості виповнених плодів до кількості елементарних суцвіть у китиці). Необхідно також враховувати здатність гречки значно коригувати кількісні показники рослини залежно від умов росту, що обумовлено індетермінантним типом розвитку. Значна частина верхівок суцвіть знаходиться в нерозвиненому стані й тривалий час зберігає здатність продовжувати свій розвиток.

У ході проведення досліджень враховувалася загальна кількість суцвіть на рослині. Розмах варіювання ознаки знаходився в межах від 25 до 127 суцвіть, при середньому значенні - 59 штук iз варіаційним розмахом 102 суцвіття на рослину. Найбільша кількість суцвіть спостерігалася у зразків пізньостиглої приморської та середньостиглої південної груп. Однак більш цінним $\epsilon$ не показник кількості суцвіть на рослині, а характеристика урожайності самого суцвіття. I за цим показником сортозразки середньостиглої південної групи значно перевищували матеріал походженням із Приморського краю. Зразки південної групи були більш ранньостиглими й низькорослими, проявляли меншу реакцію на зміну погодних умов, тривалий час зберігали здатність до цвітіння й плодоношення за підвищених температур і низькій вологості.

Доцільність використання показника «відношення довжини зони гілкування до зони плодоутворення» у селекційній практиці було доведено співробітниками Інституту круп'яних культур Подільської аграрно-технічної академії [2]. Ці показники - доступні для використання на всіх етапах селекційного процесу, не енергота трудоємкі, мають корисну інформацію, що вказує на продуктивність роботи вегетативної маси 3 формування репродуктивної сфери. 
У ході виконання завдання - селекції сортів інтенсивного типу для інтенсивних енергозберігаючих технологій - головним $\epsilon$ створення сортів, здатних за контрольовано обмеженого росту формувати значну кількість зерна. На сьогодні вже створено чимало одностебельних та детермінантних сортозразків, але їх рівень урожайності недостаній. Проведення добору за показниками величини вегетативної та генеративної мас дає можливість виявити такі форми, які за значного обмеження ростових процесів здатні формувати високий урожай. $\mathrm{У}$ роботі $з$ колекційним матеріалом важливим $\epsilon$ виявлення з-поміж сортового різноманіття колекції тих сортозразків, що володіють більшою потенційною здатністю до формування врожаю за рахунок меншої генеративної сфери. Проте необхідною умовою залишається і високе прикріплення нижнього продуктивного суцвіття для зменшення втрат у процесі збирання.

Величина вегетативної зони стебла визначає строки настання у рослин фази цвітіння, а розвиток цієї ознаки у верхніх гілок визначає синхронність зацвітання рослини. Енергійніше проходить цвітіння у тих рослин, що мають менший проміжок у ході зацвітання квіток на суцвіттях стебла і верхніх гілках [15].

Більш оптимальним $\epsilon$ наявність в урожайних сортів близького до одиниці коефіцієнта співвідношення вказаних вище зон, що дає можливість формувати високе прикріплення нижнього суцвіття та компактну форму зони плодоношення рослини. Найбільше відповідали вказаним характеристики рослин у зразків південної середньостиглої та скоростиглої північної груп. Рослини даних груп формували урожайність не за рахунок надмірного росту й цвітіння, а завдяки кращій забезпеченості генеративного апарату листо-стебловою масою, іiі стійкістю до дії екстремальних умов середовища.

Основним показником, що характеризує адаптивні й продуктивні можливості сорту, $є$ середня кількість вегетативних вузлів на рослині (потенціал гілкування сорту). Селекція гречки на урожайність повинна бути спрямована на формування популяцій із заданою архітектонікою рослин [15].

Система гілкування рослин гречки визначається кількістю вегетативних вузлів на головному стеблі та гілках першого порядку. За даними О. М. Фесенка та ін. [16], характерною особливістю всіх морфотипів $\epsilon$ наявність на двох верхніх гілках двох вегетативних вузлів. Таким чином, морфогенез рослин у ланцюгу стебло + Г1 + Г2 виражається формулою $3+2+2$, $4+2+2,5+2+2$ і т. д. Проведений ним аналіз рослин гречки місцевих популяцій зі східноєвропейської частини ареалу виявив рослини 3 обмеженим гілкуванням із редукованою вегетативною зоною у гілок першого та другого порядку, кількість яких зростала 3 просуванням із півдня на північ. Обстежений нами генетичний матеріал походженням із контрастних за тривалістю вегетаційного періоду зон вказує на наявність більш широкого різноманіття за вказаними показниками. Серед сортозразків походженням із пізньостиглої приморської та середньостиглої гірської груп виявлено матеріал, що має від трьох до п’яти вегетативних вузлів на верхніх гілках першого порядку і більше двох вегетативних вузлів - на гілках другого, хоча у зразків середньостиглої південної та скоростиглої північної груп таких зразків виявлено не було. Дослідженнями встановлено наявність у більшості сортозразків особин, які мали редуковану зону гілкування, особливо в плані зменшення кількості, або повну відсутність гілок другого та інших порядків. Встановлено, що навіть у разі незначної загущеності посівів більшість зразків різко зменшувала гілкування, формуючи повноцінні суцвіття лише на верхівках стебла та верхніх гілках першого порядку.

Висновки. На основі проведених досліджень було встановлено, що:

1. Найбільшою продуктивністю серед еколого-географічних груп гречки вирізняються зразки середньостиглої південної групи, що можна пояснити кращою пристосованістю цього матеріалу до місцевих умов вирощування, більшим проявом їх адаптивного потенціалу жаровитривалості та посухостійкості.

2. Аналіз результатів групи вивчення вказує на значну залежність показника кількості зерен на рослині як від походження матеріалу, так і від погодних умов. Найменшу кількість зерен на рослині формували зразки середньостиглої гірської групи, а найбільшу - середньостиглої південної.

3. Проведений аналіз маси 1000 зерен підтверджує дані низки дослідників про значну обумовленість величини цього показника генотипом. Найбільш крупне зерно формувалося колекційним матеріалом із середньостиглої південної групи. Серед сортозразків інших груп зустрічався також матеріал, що мав крупне зерно, але часто крупність визначалася підвищеною крилатістю матеріалу з низьким виходом крупи. 
4. Сортозразки контрастних еколого-географічних груп (пізньостиглої приморської та скоростиглої північної) мали підвищену реакцію на зміни умов середовища за показником урожайності. Найвищою урожайністю за період проведення досліджень характеризувалися зразки середньостиглої південної групи, потенціал урожайності яких реалізовувався у звичних для даного матеріалу умовах.

5. Встановлено, що найбільшою й стабільною по роках гіллястістю вирізняються рослини пізньостиглої приморської групи та зразки походженням із Китаю. Найменш гіллястими виявився матеріал скоростиглої північної групи, хоча серед цієї групи виявлено розподіл величини показника в залежності від регіону походження.

6. Найбільша кількість суцвіть спостерігалася у зразків пізньостиглої приморської та середньостиглої південної груп. Однак за показником озерненості суцвіть сортозразки середньостиглої південної групи значно перевищували матеріал походженням із Приморського краю.

7. Встановлено, що в роботі 3 колекційним матеріалом важливим $\epsilon$ виявлення серед сорто-

\section{БІБЛІОГРАФІЯ}

1. Алексеева Е. С. Культура грачихи / Е. С. Алексеева, М. М. Малина, Л. К. Тараненко [и др.] // Ч. 1. История культуры, ботанические и биологические особенности. - Каменец-Подольский: Издатель Мошак М. И., 2005. - 192 с.

2. Алексеєва E. C. Морфо-биологическая характеристика мутантов гречихи, как исходного материала для селекции / Е. С. Алексеєва, Л. П. Бочкарёва // Сельскохозяйственная биология, 1984. - №11. C. 22-24.

3. Бочкарева Л. П. Анализ структуры растения гречихи (Методические рекомендации) / Л. П. Бочкарёва. - Черновцы, 1994. - 45 с.

4. Горина Е. Д. Приёмы улучшения урожайных качеств семян гречихи Тереховская местная / Е. Д. Горина // Вопросы семеноводства, семеноведения и контрольно-семенного дела. - К. : Урожай, 1964. - Вып. 2. - С. 176-179.

5. Ефименко Д. Я. Гречиха / Д. Я. Ефименко, Г. И. Барабаш. - М. : ВО Агропромиздат, 1990. $192 \mathrm{c}$.

6. Кротов А. С. Гречиха / А. С. Кротов // Методические рекомендации по изучению коллекционных образцов кукурузы, сорго, и крупяных культур. Л. : Издательство ВИР, 1968. - С. 37-44.

7. Кротов А. С. Крупяные культуры / А. С. Кротов // Культурная флора СССР. - Л., 1975. С. 1-118. вого різноманіття колекції тих сортозразків, що володіють більшою потенційною здатністю до формування врожаю за рахунок меншої генеративної сфери. Поряд із тим, необхідно умовою залишається високе прикріплення нижнього продуктивного суцвіття для зменшення втрат у ході збирання.

8. Серед сортозразків походженням iз пізньостиглої приморської та середньостиглої гірської груп виявлено матеріал, що має від трьох до п'яти вегетативних вузлів на верхніх гілках першого порядку і більше двох вегетативних вузлів - на гілках другого, хоча в зразків середньостиглої південної та скоростиглої північної груп таких зразків виявлено не було.

9. Дослідженнями встановлено наявність у більшості сортозразків особин, що мали редуковану зону гілкування: зменшення кількості або повну відсутність гілок другого та інших порядків. Встановлено, що навіть у разі незначної загущеності посівів більшість зразків різко зменшували гілкування, формуючи повноцінні суцвіття лише на верхівках стебла i верхніх гілках першого порядку.

8. Петелина Н. Н. Создание исходного материала для селекции крупноплодных сортов диплоидной гречихи / Н. Н. Петелина // Науч. тр. ВНИИЗбК. - Орёл, 1971. - Т. 3. - С. 128-135.

9. Сірик П. А. Біологія кореневої системи гречки / П. А. Сірик // Н.т. - Т.ІХ. - К., 1959. - 95 с.

10. Тараненко Л. К. Генетическое обоснование совершенствования методов селекции гречихи Fagopyrum esculentum Moench : Диссертация докт. биолог. наук: 06.01.05. - Харьков, 1989. $383 \mathrm{c}$.

11. Тараненко Л. К. Озернённость и её связь с урожайностью / Л. К. Тараненко, А. Ф. Бобер // Генетика, селекция и возделывание гречихи. М. : Колос, 1976. - С. 133-137.

12. Фесенко А. Н. Редукция вегетативной системы как интегральный фактор селекции гречихи / А. Н. Фесенко, Н. В. Фесенко, О. А. Шипулин // Доклады РАСХН, 2008. - №5. - С. 10-13.

13. Фесенко H. В. Генофонд и селекция крупяных культур. Гречиха / Н. В. Фесенко, Н. Н. Фесеанко, О. И. Романова, Е. С. Алексеева, Г. Н. Суворова. Под ред. В. А. Драгавцева. - СПб. : ГНЦ РФ ВИР, 2006. - $196 \mathrm{c}$.

14. Фесенко А. Н. Роль морфогенеза в адаптации гречихи посевной к условиям восточноевропейской части её ареала / А. Н. Фесенко, 
Н. В. Фесенко // Повышение устойчивости производства сельскохозяйственных культур в современных условиях : Сборник научных материалов. - Орел : ПФ «Картуш», 2008. - С. 168-181. 15. Фесенко A. H. Влияние локуса LIMITED SECONDARY BRANCHING (LSB) на развитие репродуктивной системы и продуктивность рас- тений гречихи // А. Н. Фесенко, Н. Н. Фесенко / Доклады РАСХН, 2006. - №3. - С. 4-6.

16. Фесенко A. Н. Перспективы селекции гомостильных популяций гречихи / А. Н. Фесенко, И. А. Гуринович, Н. В. Фесенко // Аграрная наука, 2008. - №3. - С. 10-12. 